\title{
Irrigation depths and yield response factor in zucchini cultivation
}

\author{
Benito M. de Azevedo ${ }^{1}$, Carlos N. V. Fernandes², Denise V. Vasconcelos ${ }^{3}$, \\ Amparo C. Garcia ${ }^{4}$, Luis G. M. de Figueredo Júnior ${ }^{5}$ \& Thales V. de A. Viana ${ }^{1}$
}

${ }^{1}$ Universidade Federal do Ceará/Centro de Ciências Agrárias/Departamento de Engenharia Agrícola. Fortaleza, CE. E-mail: benitoazevedo@hotmail.com
- ORCID: 0000-0001-7391-1719; thales@ufc.br - ORCID: 0000-0003-0722-6371
${ }^{2}$ Instituto Federal do Ceará/Campus Iguatu/Departamento de Ensino. Iguatu, CE. E-mail: newdmar@gmail.com (Corresponding author) - ORCID:
0000-0001-8678-021X
${ }^{3}$ Instituto Federal do Pará/Campus Bragança/Departamento de Ensino. Bragança, PA.E-mail: denisevasconcelos@hotmail.com-ORCID: 0000-0002-3298-4812
${ }^{4}$ Universidade de São Paulo/Escola Superior de Agricultura Luiz de Queiroz/Engenharia de Sistemas Agrícolas. Piracicaba, SP. E-mail: amparocisneros@hotmail.com
- ORCID: 0000-0002-8356-3014
${ }^{5}$ Universidade Estadual do Piauí/Campus Torquato Neto/Centro de Ciências Agrárias. Teresina, PI.E-mail:luisjruespi@gmail.com - ORCID: 0000-0002-2294-7225

\section{Key words:}

Cucurbita pepo L. irrigation management reference evapotranspiration

\begin{abstract}
A B S T R A C T
The objective of this study was to evaluate the effect of different irrigation depths on productive performance and yield response of zucchini (Cucurbita pepo L.). A field trial was carried out in the experimental area of the Meteorological Station of the Federal University of Ceará, CE, Brazil. The experimental design was randomized blocks, with six treatments and four replicates. The treatments adopted were: $30,60,90,120,150$ and $180 \%$ of the reference evapotranspiration (ETo), estimated by Penman-Monteith (EToPM) and applied by drip irrigation. Fruit weight, number of fruits, fruit length, fruit diameter, pulp thickness, soluble solids and yield were analyzed, as well as water use efficiency (WUE). The methodology proposed by FAO Bulletin 33 was used to calculate the yield response factor (Ky). The $567 \mathrm{~mm}$ irrigation depth equivalent to $159 \%$ EToPM led to the maximum total crop yield estimated at $24,808 \mathrm{~kg} \mathrm{ha}^{-1}$. Highest WUE $\left(64 \mathrm{~kg} \mathrm{~mm}^{-1}\right)$ was found for the total irrigation depth of $186 \mathrm{~mm}$ (30\% ETo). Ky values indicated that the crop could be considered as little sensitive $(\mathrm{Ky}<1)$ to water deficit $(50,60$, 70,80 and $90 \%$ of the optimal water depth), tending to be proportionally sensitive $(\mathrm{Ky}=1)$ to more severe water deficits (30,60 and 90\% EToPM).
\end{abstract}

\section{Palavras-chave:}

Cucurbita pepo L. manejo da irrigação evapotranspiração de referência

\section{Lâminas de irrigação e fator de resposta ao rendimento no cultivo da abobrinha}

\section{R E S U M O}

Objetivando-se avaliar o efeito de diferentes lâminas de irrigação no desempenho produtivo e o fator de resposta ao rendimento da abobrinha (Cucurbita pepo L.), realizou-se um ensaio de campo na área experimental da Estação Meteorológica da Universidade Federal do Ceará, CE. O delineamento utilizado foi o de blocos ao acaso, com seis tratamentos e quatro repetições. Os tratamentos adotados foram: 30, 60, 90, 120, 150 e 180\% da evapotranspiração de referência (ETo), estimada por Penman-Monteith (EToPM) e aplicadas por gotejamento. Analisou-se a: massa do fruto, número de frutos, comprimento do fruto, diâmetro do fruto, espessura da polpa, sólidos solúveis e produtividade, além da eficiência de uso da água (EUA). Para o cálculo do fator de resposta ao rendimento $(\mathrm{Ky})$ utilizou-se a metodologia proposta pelo boletim 33 da FAO. A lâmina de irrigação de $567 \mathrm{~mm}$ equivalente a 159\% da EToPM proporcionou a máxima produtividade total da cultura estimada em $24.808 \mathrm{~kg} \mathrm{ha}^{-1}$. A EUA apresentou o maior valor de $64 \mathrm{~kg} \mathrm{~mm}^{-1}$, para a lâmina de irrigação totalizada em $186 \mathrm{~mm}$ (30\% da ETo). Os valores de Ky indicaram que a cultura pode ser considerada pouco sensível $(\mathrm{Ky}<1)$ ao déficit hídrico (50, 60, 70, 80 e 90\% da lâmina ótima), com tendência a ser proporcionalmente sensível $(\mathrm{Ky}=1)$ para déficits hídricos mais severos (30, 60 e 90\% da EToPM). 


\section{INTRODUCTION}

Zucchini (Cucurbita pepo L.) is a cucurbit cultivated in all regions of Brazil, mainly exploited in family farming (Costa et al., 2015). It has great importance in the economy as a vegetable due to its high yield, good acceptability in the market and fast financial return (Azambuja et al., 2015).

Due to the constant occurrence of water deficit in the Northeast region, irrigation is frequently used to cultivate zucchini, a practice that requires adequate management in order to make the most of its potential benefits (Carvalho et al., 2011; Oliveira et al., 2012), avoiding negative effects caused by either water deficit (Delazari et. al., 2017) or water excess (Viana et al., 2012).

The variability of optimal water depths that enhance yield, obtained by different authors, associated with the influence from various edaphoclimatic factors, reinforces the importance of conducting local trials (Azevedo et al., 2016). Sousa et al. (2010) with melon in Fortaleza-CE, Silva et al. (2011) with carrot in Itumbiara-GO, and Saraiva et al. (2017) with watermelon in Limoeiro do Norte-CE, found water depths of $795,2,310$ and $365 \mathrm{~mm}$, respectively. For zucchini, there is a lack of such information in the specialized literature.

Nonetheless, the use of optimal irrigation depths is not always a technically adequate strategy in areas with water scarcity. In these cases, the utilization of water use efficiency indicators helps the selection of crops and efficient water management, identifying favorable conditions of cultivation, even with the adoption of sub-optimal irrigation depths (Morais et al., 2017).

For Steduto et al. (2012), the yield response factor (Ky) captures the essences of the complex linkages between production and water use by a crop and can be used to evaluate drastic yield reductions under limited water supply, besides supporting the planning and execution of irrigation management (Silva et al., 2014).

Thus, this study aimed to evaluate the influence of different irrigation depths on the productive performance and yield response factor of zucchini.

\section{Material AND Methods}

The experiment was carried out from September 16 to November 21, 2013, in the experimental area of the Meteorological Station of the Federal University of Ceará (UFC), Fortaleza-CE, Brazil (3 44’ S; 38 33’ W; 19.5 m). The climate of the region is Aw' (Köppen, 1931), rainy tropical, with rainfalls predominantly in the summer-autumn.

Mean monthly data of climatic variables collected along the experiment are presented in Table 1.

The physical and chemical characteristics of the Red Yellow Argisol (EMBRAPA, 2006), for the 0-20 cm layer using EMBRAPA (1997) methodologies, were: fine sand $\left(386 \mathrm{k} \mathrm{kg}^{-1}\right)$; coarse sand $\left(405 \mathrm{~g} \mathrm{~kg}^{-1}\right)$; silt $\left(96 \mathrm{~g} \mathrm{~kg}^{-1}\right)$; clay $\left(113 \mathrm{~g} \mathrm{~kg}^{-1}\right)$; bulk density $\left(1.43 \mathrm{~g} \mathrm{~cm}^{-3}\right)$; particle density $\left(2.57 \mathrm{~g} \mathrm{~cm}^{-3}\right)$; field capacity

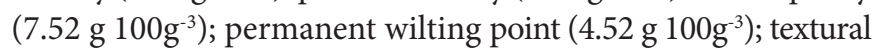
class (sandy loam); $\mathrm{K}^{+}\left(0.11 \mathrm{cmol} \mathrm{dm}^{-3}\right) ; \mathrm{Na}^{+}\left(0.06 \mathrm{cmol}_{c} \mathrm{dm}^{-3}\right) ; \mathrm{Ca}^{2+}$ $\left(1.7 \mathrm{cmol}_{c} \mathrm{dm}^{-3}\right) ; \mathrm{Mg}^{2+}\left(1.2 \mathrm{cmol}_{c} \mathrm{dm}^{-3}\right) ; \mathrm{H}^{+}+\mathrm{Al}^{3+}\left(1.65 \mathrm{cmol}_{c} \mathrm{dm}^{-3}\right)$ $\mathrm{Al}^{3+}\left(0.1 \mathrm{cmol}_{c} \mathrm{dm}^{-3}\right) ; \mathrm{pH}(5.8)$; EC $\left(0.20 \mathrm{dS} \mathrm{m}^{-1}\right)$.
Table 1. Monthly data of climatic variables along the experiment

\begin{tabular}{lccccc}
\hline Month & $\begin{array}{c}\text { Air } \\
\text { temperature } \\
\left({ }^{\circ} \mathbf{C}\right)\end{array}$ & $\begin{array}{c}\text { Relative air } \\
\text { humidity } \\
(\%)\end{array}$ & $\begin{array}{c}\text { Wind } \\
\text { speed } \\
\left(\mathbf{m ~ s}^{-1}\right)\end{array}$ & $\begin{array}{c}\text { Rainfall } \\
(\mathbf{m m})\end{array}$ & $\begin{array}{c}\text { EToPM } \\
\left(\mathbf{m m ~ d}^{-1}\right)\end{array}$ \\
September & 27.1 & 64 & 4.4 & 16.7 & 5.96 \\
October & 27.5 & 75 & 4.5 & 10.1 & 6.08 \\
November & 27.5 & 68 & 4.3 & 5.7 & 5.76 \\
\hline
\end{tabular}

EToPM - Reference evapotranspiration obtained by the Penman-Monteith method Source: Meteorological Station of the Federal University of Ceará

The statistical design was randomized blocks, comprising of six treatments and four blocks (replicates). Treatments corresponded to irrigation depths: 30, 60, 90, 120, 150 and 180\% of the ETo determined by Penman-Monteith (EToPM, $\mathrm{mm} \mathrm{d}^{-1}$ ), using daily climatic data of an automatic meteorological station located $30 \mathrm{~m}$ away from the experimental area (Allen et al., 2006).

Zucchini, hybrid Corona F1, was directly sown in the soil at spacing of $1.0 \mathrm{~m}$ between rows and $0.6 \mathrm{~m}$ between plants. Each experimental plot occupied an area of $3.6 \mathrm{~m}^{2}(3.6 \times 1.0 \mathrm{~m})$, containing six plants.

A drip irrigation system was used, composed of one lateral line per plant row. Each lateral line was $3.6 \mathrm{~m}$ long, made of polyethylene pipe, and drippers were spaced by $0.6 \mathrm{~m}$ with nominal flow rate of $4 \mathrm{~L} \mathrm{~h}^{-1}$, at constant pressure of $100 \mathrm{kPa}$.

Irrigation management consisted in daily applications, according to the climatological water balance, simplified in Eq. 1.

$$
\mathrm{AIN}=\mathrm{EToPM}-\mathrm{Pe}
$$

where:

AIN - actual irrigation needed, $\mathrm{mm}$;

EToPM - reference evapotranspiration of Penman-Monteith, $\mathrm{mm}$; and,

$\mathrm{Pe} \quad$ - effective rainfall, $\mathrm{mm}$.

The Pe, calculated according to the method of the United States Soil Conservation Service (Smith, 1992), was not accumulated for the next day ( $\mathrm{Pe} \leq \mathrm{ETo}$ ).

Total irrigation needed was estimated by Eq. 2.

$$
\operatorname{TIN}=\operatorname{AIN}\left(\frac{\mathrm{Int}}{\mathrm{CUC}}\right)
$$

where:

TIN - total irrigation needed, $\mathrm{mm}$;

AIN - actual irrigation needed, $\mathrm{mm}$;

Int - irrigation interval, day; and,

CUC - Christiansen uniformity coefficient, decimal.

Treatments differentiation started at 16 days after planting (DAP) and, until 15 DAP, all plants received equal irrigation depths corresponding to $100 \%$ EToPM $(83.3 \mathrm{~mm})$. The total irrigation depths equivalent to the treatments were $186.3 \mathrm{~mm}$ (30\% EToPM), $277.4 \mathrm{~mm}$ (60\% EToPM), $368.4 \mathrm{~mm}(90 \%$ EToPM), $459.5 \mathrm{~mm}$ (120\% EToPM), $550.6 \mathrm{~mm}$ (150\% EToPM) and $641.6 \mathrm{~mm}$ (180\% EToPM).

Fertilization was performed according to soil analyses and recommendations of Filgueira (2012), by applying: $140 \mathrm{~kg} \mathrm{ha}^{-1}$ of 
nitrogen (Urea - 45\% N); $300 \mathrm{~kg} \mathrm{ha}^{-1}$ of phosphorus (Single superphosphate - $\left.18 \% \mathrm{P}_{2} \mathrm{O}_{5}\right) ; 150 \mathrm{~kg} \mathrm{ha}^{-1}$ of potassium (Potassium chloride $-60 \% \mathrm{~K}_{2} \mathrm{O}$ ) and $2 \mathrm{~kg} \mathrm{ha}^{-1}$ of boron (Boric acid - 17\% B).

All phosphorus was applied at planting, besides one third of $\mathrm{N}$, one third of $\mathrm{K}_{2} \mathrm{O}$ and the entire dose of $\mathrm{B}$. The remaining dose of $\mathrm{N}$ was split into two applications (15 and $30 \mathrm{DAP})$, while the remaining dose of $\mathrm{K}_{2} \mathrm{O}$ was applied at once (15 DAP). All fertilizations were performed through fertigation, except phosphate.

Harvest was carried out from October 21 to November 21,2013 . The following variables were analyzed: fruit weight (FW), number of fruits (NF), fruit length (FL), fruit diameter (FD), pulp thickness (PT), soluble solids (SS) and yield (Y).

Mean data of these variables were subjected to analysis of variance by $F$ test $(\mathrm{p}<0.01$ and $\mathrm{p}<0.05)$ and, when significant effect was observed, subjected to regression analysis. The analyses were carried out using the programs Microsoft Office Excel (version 2010) and Assistat 7.7 (Silva \& Azevedo, 2016).

Water use efficiency was calculated using Eq. 3.

$$
\mathrm{WUE}=\frac{\mathrm{y}}{\mathrm{W}}
$$

where:

$$
\begin{aligned}
& \text { WUE - water use efficiency, } \mathrm{kg} \mathrm{ha}^{-1} \mathrm{~mm}^{-1} \text {; } \\
& \mathrm{Y} \quad \text { - crop yield, } \mathrm{kg} \mathrm{ha}^{-1} \text {; and, } \\
& \mathrm{W} \text { - total water depth applied along the cycle, } \mathrm{mm} \text {. }
\end{aligned}
$$

The yield response factor was estimated by Eq. 4 (Doorenbos \& Kassam, 1979).

$$
\left(1-\frac{\mathrm{Ya}}{\mathrm{Ym}}\right)=\mathrm{Ky}\left(1-\frac{\mathrm{ETa}}{\mathrm{ETm}}\right)
$$

where:

Ky - cropyield response factor to water deficit, dimensionless;

Ya - actual yield, $\mathrm{kg} \mathrm{ha}^{-1}$;

Ym - maximum yield, $\mathrm{kg} \mathrm{ha}^{-1}$;

ETa - actual evapotranspiration, $\mathrm{mm}$; and,

ETm - maximum evapotranspiration, $\mathrm{mm}$.

Ky was determined for two intervals of data. For the first one, maximum values of yield and evapotranspiration were considered as those obtained with the total water depth equivalent to $100 \%$ EToPM, while the actual values were considered as those obtained with 30,60 and 90\% EToPM. For the second interval, the maximum values were obtained with the optimal water depth equivalent to $155.5 \%$ EToPM $(566.5 \mathrm{~mm})$, while actual values were assumed to be $50 \%$ (283.3 $\mathrm{mm}), 60 \%$ (339.9 $\mathrm{mm})$, $70 \%$ (396.6 mm), 80\% (453.2 $\mathrm{mm})$ and $90 \%(509.9 \mathrm{~mm})$ of the optimal irrigation depth (optimal EToPM).

Optimal irrigation depths and yield values of the deficits were calculated by the equation obtained from the 'yield $v s$ net irrigation depth' relationship $\left(y=-0.0957 x^{2}+108.43 x-5904.9\right)$.

For both intervals, Ky values were considered as the angular coefficient of the linear regression equation, adjusted by the origin, between relative yield reduction and relative evapotranspiration deficit (Bilibio et al., 2010). Zucchini sensitivity to water deficit was classified according to the FAO Bulletin 66 as: very sensitive $(\mathrm{Ky}>1)$, proportionally sensitive $(\mathrm{Ky}=1)$ and little sensitive $(\mathrm{Ky}<1)$ (Steduto et al., 2012).

\section{Results AND Discussion}

Fruit weight (FW), number of fruits (NF) and yield (Y) were significantly affected by the different irrigation depths applied in the zucchini crop ( $<0.01$ and/or $\mathrm{p}<0.05)$ (Table 2) and showed a quadratic polynomial response (Figures $1 \mathrm{~A}, \mathrm{~B}$ and $\mathrm{C}$ ).

The obtained models were used to estimate the maximum values for the variables, and maximum FW of $684.69 \mathrm{~g}$ was obtained with an optimal irrigation depth of $618 \mathrm{~mm}$, corresponding to $174 \%$ EToPM. Maximum NF was 2.30 fruits per plant and maximum yield was $24,808 \mathrm{~kg} \mathrm{ha}^{-1}$, both for an irrigation depth of $566.5 \mathrm{~mm}$ (155.5\% EToPM).

FW values obtained in all treatments were higher than the one described for the hybrid by the selling company, $175 \mathrm{~g}$, and the optimal irrigation depth led to $291 \%$ increment in this variable.

Due to the lack of information on the zucchini crop, the results were compared with values obtained for other vegetables. Similar results were found by Melo et al. (2010), for the watermelon crop under different levels of irrigation. These authors obtained quadratic polynomial curve, reaching maximum of $52,400 \mathrm{~kg} \mathrm{ha}^{-1}$ with irrigation depth of $266 \mathrm{~mm}$ (130\% ETo obtained by Class A pan evaporation)

Also using cucurbits, Sousa et al. (2010) observed that melon fruit yield increased linearly with the applied water depth and was maximized $\left(34,800 \mathrm{~kg} \mathrm{ha}^{-1}\right)$ with the irrigation depth of $795 \mathrm{~mm}$ (150\% of Class A pan evaporation). In a study also using melon, Faria et al. (2015) obtained quadratic responses for postharvest characteristics, rind thickness and $\mathrm{pH}$.

For pepper, Azevedo et al. (2005) evaluated irrigation depths in Pentecoste-CE and observed increasing linear response in its yield. Similar response was reported by

\begin{tabular}{|c|c|c|c|c|c|c|c|c|}
\hline \multirow{2}{*}{ SV } & \multirow{2}{*}{ DF } & \multicolumn{7}{|c|}{ Mean square } \\
\hline & & FW & NF & FL & FD & PT & SS & $\bar{Y}$ \\
\hline Blocks & 3 & $8,712^{\mathrm{ns}}$ & $0.05^{\mathrm{ns}}$ & $3.23^{\text {ns }}$ & $26.40^{\text {ns }}$ & $0.62^{\text {ns }}$ & $0.02^{\text {ns }}$ & $9,619,444^{\mathrm{ns}}$ \\
\hline Treatments & 5 & $26,667^{* *}$ & $0.41^{*}$ & $2.62^{\text {ns }}$ & $22.08^{\mathrm{ns}}$ & $5.05^{\mathrm{ns}}$ & $0.26^{\text {ns }}$ & $126,382,397^{* \star}$ \\
\hline Residual & 15 & 4,498 & 0.12 & 5.30 & 43.30 & 3.25 & 0.09 & $18,948,226$ \\
\hline Total & 23 & - & - & - & - & - & - & - \\
\hline CV\% & - & 10.99 & 18.26 & 10.79 & 9.36 & 13.76 & 10.10 & 21.50 \\
\hline
\end{tabular}
Rebouças Neto et al. (2017) for the tomato crop.

Water depths lower than optimal may cause water stress, greatly reducing the production and even making it unviable,

Table 2. Analysis of variance for zucchini production variables

${ }^{* *}$ Significant at 0.01 probability level by F test; ; Significant at 0.05 probability level by F test; (ns) Not significant by F test. SV - Source of variation; DF - Degrees of freedom; FW - Fruit weight; NF - Number of fruits; FL - Fruit length; FD - Fruit diameter; PT - Pulp thickness; SS - Soluble solids; Y - Yield 
A.

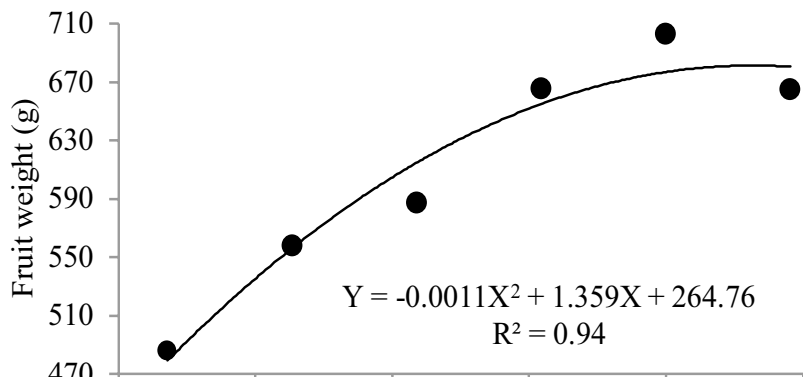

B.
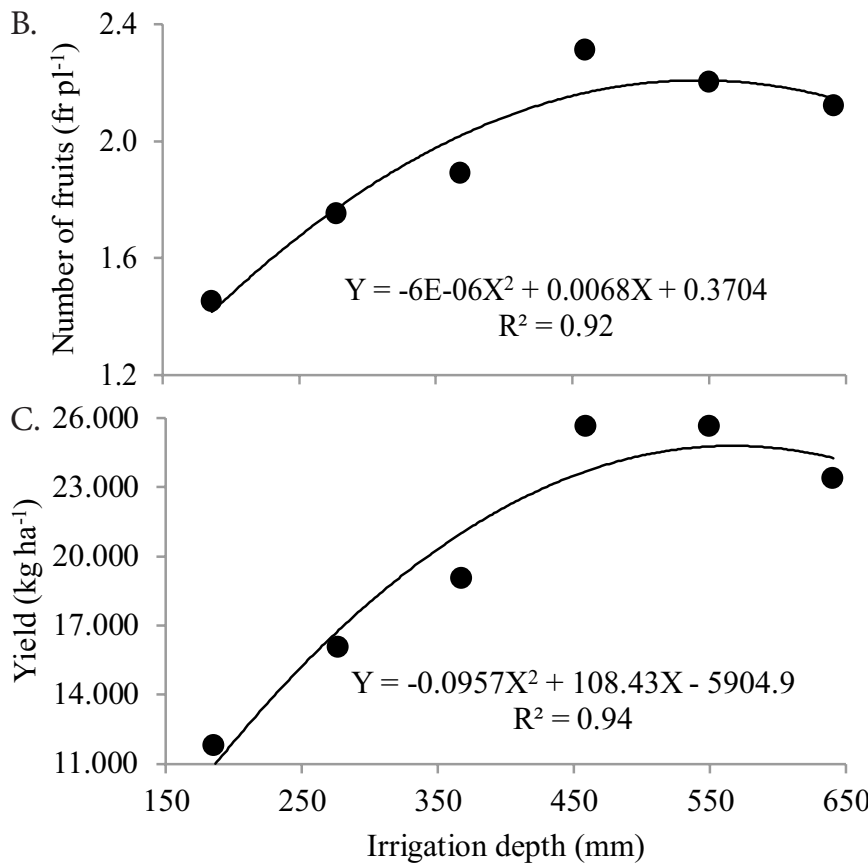

Figure 1. Fruit weight (A), number of fruits (B) and yield (C) of zucchini as a function of irrigation depth

especially in regions of arid or semi-arid climate, where the lack of water limits the agricultural activity. On the other hand, water excess reduces aeration, affecting the absorption of nutrients, facilitating the appearance of diseases and allowing for the leaching of nutrients (Viana et al., 2012). These claims can justify the responses found in the present study.

Therefore, the use of a correct irrigation depth promotes maintenance of plant metabolic activity, through the capture of $\mathrm{CO}_{2}$ from the atmosphere and absorption of nutrients from the soil, allowing for an adequate production of photoassimilates and, consequently, better productive response (Melo et al., 2010).

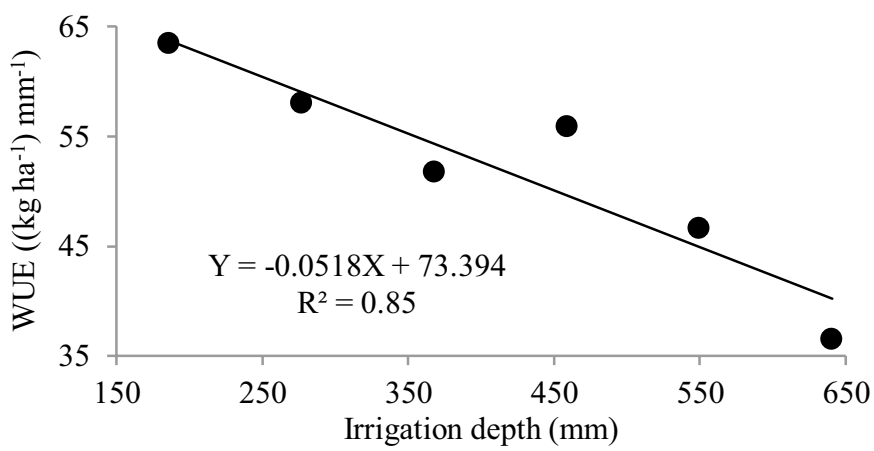

Figure 2. Water use efficiency (WUE) of zucchini as a function of irrigation depth

For water use efficiency, the decreasing linear model was the most adequate (Figure 2) and such response is commonly reported in the literature.

Sousa et al. (2010), for the melon crop, observed reduction of WUE as irrigation depth (ID) increased; highest value $\left(74.65 \mathrm{~kg} \mathrm{ha}^{-1} \mathrm{~mm}^{-1}\right)$ was found with the lowest ID $(265 \mathrm{~mm})$, $61.20 \%$ higher than the lowest value $\left(43.75 \mathrm{~kg} \mathrm{ha}^{-1} \mathrm{~mm}^{-1}\right)$ relative to the highest ID $(795 \mathrm{~mm})$.

Highest estimate of WUE was equal to $64 \mathrm{~kg} \mathrm{ha}^{-1} \mathrm{~mm}^{-1}$, relative to the lowest ID, which is $58.9 \%$ higher than the WUE of $40 \mathrm{~kg} \mathrm{ha}^{-1} \mathrm{~mm}^{-1}$ obtained with the highest ID $(642 \mathrm{~mm})$ and $44.8 \%$ higher than the WUE of $44 \mathrm{~kg} \mathrm{ha}^{-1} \mathrm{~mm}^{-1}$ obtained with the ID of $567 \mathrm{~mm}$, which guaranteed maximum physical yield of the crop. Such response can be explained by the capacity of the stomata to reduce their conductance to water vapor in response to the water deficit, promoting lower water loss per unit of carbon assimilation, thus improving water use efficiency in stressed plants (Silva et al., 2017).

Based on Ky values, it is observed that in the first interval the $30 \%$ EToPM treatment led to Ky close to 1, evidencing a proportional sensitivity of the crop to a high water deficit, whereas in the treatments with 60 and 90\% EToPM the coefficients were 21 and $37 \%$ lower than 1, respectively. According to the regression, Ky value of 0.90 is only $10 \%$ lower than 1 (Table 3 and Figure 3A).

For the second interval, lower Ky values were observed, which were 38 to $88 \%$ lower than 1 . These results are probably associated with the use of water deficits from $50 \%$ optimal EToPM. Likewise, lower Ky was also found in the regression (Figure 3B), equal to 0.51 , i.e., $49 \%$ lower than 1.

According to the obtained results, the crop is little sensitive $(\mathrm{Ky}<1)$ to water deficits of up to $50 \%$ optimal EToPM $(283 \mathrm{~mm})$,

Table 3. Actual evapotranspiration (ETa), maximum evapotranspiration (ETm), relative evapotranspiration deficit (1 - ETa/ETm), actual yield (Ya), maximum yield (Ym), relative yield reduction (1 - Ya/Ym) and water deficit response factor $(\mathrm{Ky})$ of zucchini for both intervals evaluated

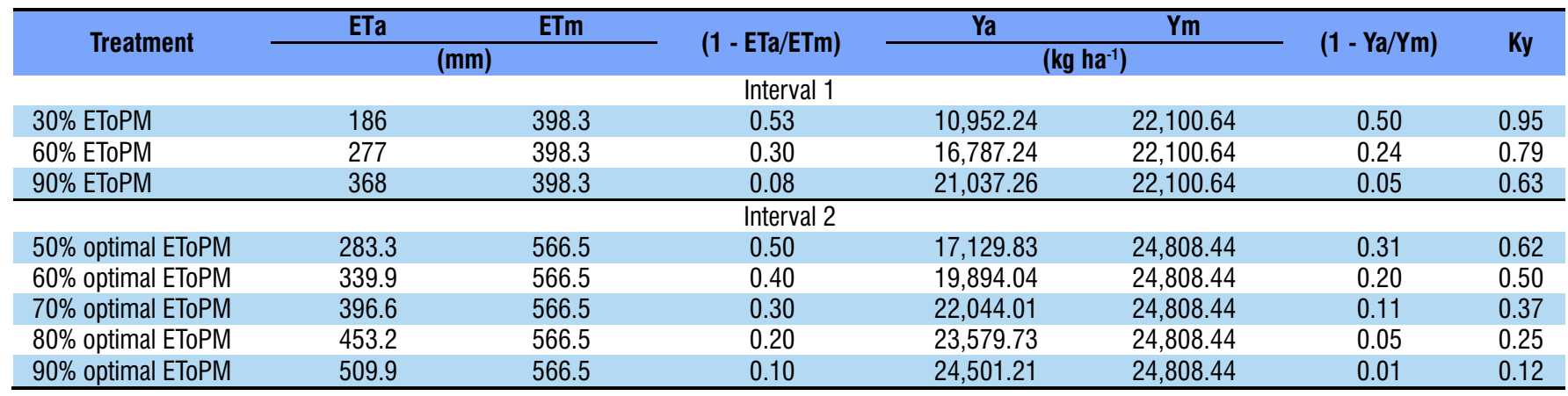


A. Relative evapotranspiration deficit (1-ETa/ETm)

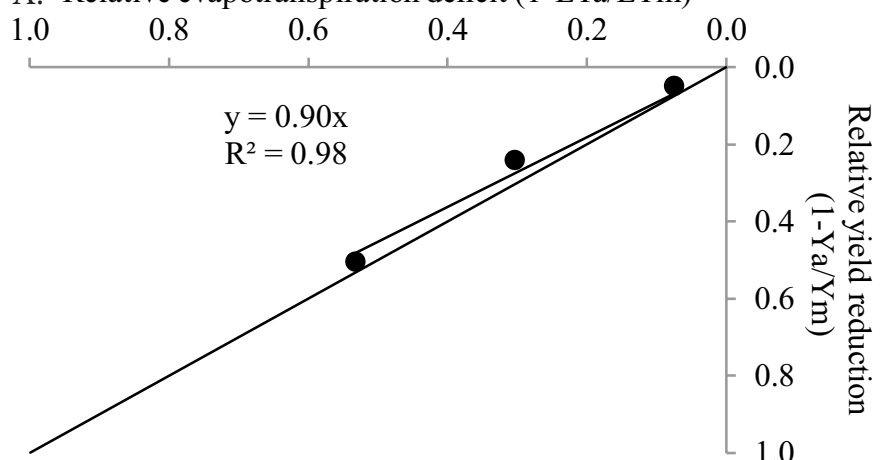

B. Relative evapotranspiration deficit (1-ETa/ETm)

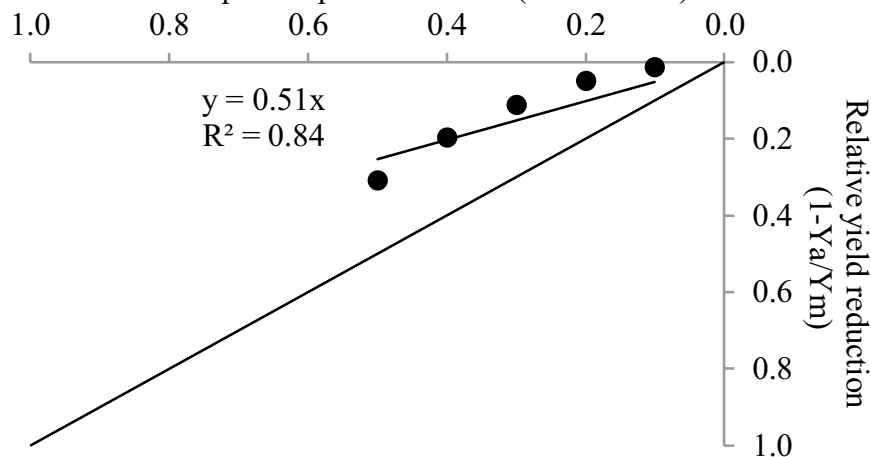

Figure 3. Water deficit response factor (Ky) of zucchini obtained with the intervals 25, 50 and 75\% EToPM (A) and 50,60, 70, 80 and 90\% optimal EToPM (B)

tending to be proportionally sensitive $(\mathrm{Ky}=1)$ to higher water deficits, up to 30\% EToPM (186 mm) (Steduto et al., 2012).

Still based on the results presented in Table 2, for the interval 2, it can be inferred that, under limiting water conditions, opting for reduction in the irrigation depth to 90,80 or even $70 \%$ optimal EToPM is a more advantageous alternative because, for these conditions, yield reduction is less than $50 \%$ of the reduction in irrigation depth $(\mathrm{Ky}<0.5)$. These irrigation depths would result in water savings of about $566,1,133$ and $1,699 \mathrm{~m}^{3} \mathrm{ha}^{-1}$, respectively.

\section{Conclusions}

1. Maximum yield of zucchini, $24,808 \mathrm{~kg} \mathrm{ha}^{-1}$, was obtained with irrigation depth of $567 \mathrm{~mm}$, equivalent to 159\% ETo of Penman-Monteith.

2. Highest water use efficiency, $64 \mathrm{~kg} \mathrm{~mm}^{-1}$, was found for irrigation depth of $186 \mathrm{~mm}$ (30\% ETo), which was $48 \%$ higher than the efficiency obtained with the optimal irrigation depth.

3. The crop can be considered as little sensitive to water deficit (50,60, 70, 80 and 90\% optimal EToPM) and tends to be proportionally sensitive to more severe water deficits (30, 60 and $90 \%$ EToPM).

4. Under limiting water conditions, reducing irrigation depth to up to $70 \%$ optimal EToPM is a more advantageous alternative $(\mathrm{Ky}<0.5)$.

\section{Literature Cited}

Allen, R. G.; Pereira, L. S.; Raes, D.; Smith, M. Evapotranspiración del cultivo: Guías para la determinación de los requerimientos de agua de los cultivos. Rome: FAO, 2006. 300p.
Azambuja, L. O.; Benett, C. G. S.; Benett, K. S. S.; Costa, E. Produtividade da abobrinha 'Caserta' em função do nitrogênio e gel hidrorretentor. Científica, v.43, p.353-358, 2015. https://doi. org/10.15361/1984-5529.2015v43n4p353-358

Azevedo, B. M. de; Bastos, F. G. C.; Viana, T. V. de A.; Rêgo, J. de L.; D’Ávila, J. H. T. Efeitos de níveis de irrigação na cultura da melancia. Revista Ciência Agronômica, v.36, p.9-15, 2005.

Azevedo, B. M. de; Vasconcelos, D. V.; Bomfim, G. V. do; Viana, T. V. de A.; Nascimento Neto, J. R. do; Oliveira, K. M. A. S. de. Production and yield response factor of sunflower under different irrigation depths. Revista Brasileira de Engenharia Agrícola e Ambiental, v.20, p.427-433, 2016. https://doi.org/10.1590/18071929/agriambi.v20n5p427-433

Bilibio, C.; Carvalho, J. de A.; Martins, M.; Rezende, F. C.; Freitas, E. A.; Gomes, L. A. A. Desenvolvimento vegetativo e produtivo da berinjela submetida a diferentes tensões de água no solo. Revista Brasileira de Engenharia Agrícola e Ambiental, v.14, p.730-735, 2010. https://doi.org/10.1590/S1415-43662010000700007

Carvalho, J. de A.; Rezende, F. C.; Aquino, R. F.; Freitas, W. A. de; Oliveira, E. C. Análise produtiva e econômica do pimentãovermelho irrigado com diferentes lâminas, cultivado em ambiente protegido. Revista Brasileira de Engenharia Agrícola e Ambiental, v.15, p.569-574, 2011. https://doi.org/10.1590/S141543662011000600005

Costa, A. R. da; Rezende, R.; Freitas, P. S. L. de; Gonçalves, A. C. A.; Frizzone, J. A. A cultura da abobrinha italiana (Cucurbita pepo L.) em ambiente protegido utilizando fertirrigação nitrogenada $e$ potássica. Irriga, v.20, p.105-127, 2015. https://doi.org/10.15809/ irriga.2015v20n1p105

Delazari, F. T.; Ferreira, M. G.; Silva, G. H. da; Dariva, F. D.; Freitas, D. S. de; Nick, C. Eficiência no uso da água e acúmulo de matéria na batata-doce em função de lâminas de irrigação. Irriga, v.22, p.115128, 2017. https://doi.org/10.15809/irriga.2017v22n1p115-128

Doorenbos, J.; Kassam, A. H. Yield response to water. Rome: FAO, 1979. 19p.

EMBRAPA - Empresa Brasileira de Pesquisa Agropecuária. Manual de métodos de análises de solo. 2.ed. Rio de Janeiro: Embrapa Solos, 1997. 212p.

EMBRAPA - Empresa Brasileira de Pesquisa Agropecuária. Sistema brasileiro de classificação de solos. 2.ed. Rio de Janeiro: Embrapa Solos, 2006. 306p.

Faria, L. do A.; Lima, E. M. de C.; Siqueira, W. da C.; Rezende, F. C.; Gomes, L. A. A. Qualidade de frutos de melão rendilhado cultivado em ambiente protegido sob diferentes lâminas de irrigação. Revista Brasileira de Agricultura Irrigada v.9, p.357-365, 2015. https://doi.org/10.7127/rbai.v9n600302

Filgueira, F. A. R. Novo manual de olericultura. 3.ed. Viçosa: Editora UFV, 2012. 421p.

Köppen, W. Grundriss der klimakunde. Berlin: W. Guyter, 1931.390p. Melo, A. S. de; Suassuna, J. F.; Fernandes, P. D.; Brito, M. E. B.; Suassuna, A. F.; Aguiar Netto, A. de O. Crescimento vegetativo, resistência estomática, eficiência fotossintética e rendimento do fruto da melancieira em diferentes níveis de água. Acta Scientiarum. Agronomy, v.32, p73-79, 2010.

Morais, J. E. F. de; Silva, T. G. F. da; Queiroz, M. G. de; Araujo, G. G. L. de; Moura, M. S. B.; Araújo Júnior, G. do N. Hydrodynamic changes of the soil-cactus interface, effective actual evapotranspiration and its water efficiency under irrigation. Revista Brasileira de Engenharia Agrícola e Ambiental, v.21, p.273-278, 2017. https:// doi.org/10.1590/1807-1929/agriambi.v21n4p273-278 
Oliveira, P. G. F. de; Moreira, O. da C.; Branco, L. M. C.; Costa, R. N. T.; Dias, C. N. Eficiência de uso dos fatores de produção água e potássio na cultura da melancia irrigada com água de reuso. Revista Brasileira de Engenharia Agrícola e Ambiental, v.16, p.153158, 2012. https://doi.org/10.1590/S1415-43662012000200004

Rebouças Neto, M. de O.; Azevedo, B. M. de; Sousa, G. G. de; Mesquita, J. B. R. de; Viana, T. V. de A.; Fernandes, C. N. V. Irrigação da cultura do tomateiro durante dois anos de cultivo no litoral de Fortaleza-CE. Revista Brasileira de Agricultura Irrigada, v.11, p.1548-1556, 2017. https://doi.org/10.7127/rbai.v11n400598

Saraiva, K. R.; Viana, T. V. de A.; Bezerra, F. M. L.; Costa, S. C.; Gondim, R. S. Regulated deficit irrigation and different mulch types on fruit quality and yield of watermelon. Revista Caatinga, v.30, p.437-446, 2017. https://doi.org/10.1590/1983-21252017v30n219rc

Silva, A. R. A. da; Bezerra, F. M. L.; Freitas, C. A. S. de; Amorim, A. V.; Carvalho, L. C. C. de; Pereira Filho, J. V. Coeficientes de sensibilidade ao déficit hídrico para a cultura do girassol nas condições do semiárido cearense. Revista Brasileira de Agricultura Irrigada, v.8, p.38-51, 2014. https://doi.org/10.7127/rbai.v8n100185

Silva, A. R. A da; Bezerra, F. M. L; Lacerda, C. F. de; Sousa, C. H. C. de; Bezerra, M. A. Physiological responses of dwarf coconut plants under water deficit in salt-affected soils. Revista Caatinga, v.30, p.447-457, 2017. https://doi.org/10.1590/1983-21252017v30n220rc
Silva, F. de A. S. e; Azevedo, C. A. V. de. The Assistat Software Version 7.7 and its use in the analysis of experimental data. African Journal of Agricultural Research, v.11, p.3733-3740, 2016. https://doi. org/10.5897/AJAR2016.11522

Silva, V. J. da; Teodoro, R. E. F.; Carvalho, H. de P.; Martins, A. D.; Luz, J. M. Q. Resposta da cenoura a diferentes lâminas de irrigação. Bioscience Journal, v.27, p.954-963, 2011.

Sousa, A. E. C.; Bezerra, F. M. L.; Sousa, C. H. C. de; Santos, F. S. S. dos. Produtividade do meloeiro sob lâmina de irrigação e adubação potássica. Engenharia Agrícola, v.30, p.271-278, 2010. https://doi. org/10.1590/S0100-69162010000200009

Smith, M. Cropwat: A computer program for irrigation planning and management. Rome: FAO, 1992. 126p.

Steduto, P.; Hsiao, T. C.; Fereres, E.; Raes, D. Crop yield response to water. Rome: FAO, 2012. 500p.

Viana, T. V. de A.; Lima, A. D.; Marinho, A. B.; Duarte, J. M. de L.; Azevedo, B. M. de; Costa, S. C. Lâminas de irrigação e coberturas do solo na cultura do girassol, sob condições semiáridas. Irriga, v.17, p.126-136, 2012. https://doi.org/10.15809/ irriga.2012v17n2p126 